\title{
APLIKASI PENGOLAHAN DATA BANTUAN SOSIAL PAGI PMKS DI DINAS SOSIAL BANJARMASIN
}

\author{
Ibrahim \\ Program Studi Sistem Informasi, Fakultas Teknologi Informasi \\ Universitas Islam Kalimantan Muhammad Arsyad Al Banjari Banjarmasin \\ Jl. Adhyaksa No.2 Kayutangi Banjarmasin 70123 \\ Email : Terrasin06@gmail.com
}

\begin{abstract}
Abstrak- Penyajian pengolahan data bantuan sosial di Dinas Sosial Prov Kalsel masih menggunakan semi komputer. Dan dirasa masih kurang efektif dan efisien menyebabkan penyajian informasi atau laporan menjadi lambat dan kurang akurat. Selain itu, tidak adanya sistem keamanan membuat data-data yang berkaitan dengan data bantuan sosial di Dinas Sosial menjadi tidak aman dan rawan akan tindakan manipulasi data oleh pihak-pihak yang tidak memiliki kewenangan dan juga menjadikan bantuan sosial agar tepat sasaran sesuai dengan aturan yang berlaku. Oleh karena itu, peneliti memandang perlu dibangunnya aplikasi khusus untuk mengelola data bantuan sosial praktik berbasis desktop Metode pengembangan perangkat lunak yang digunakan untuk membangun aplikasi data bantuan sosial bagi penyandang masalah kesejahteraan sosial adalah metode pengembangan perangkat lunak dengan model waterfall. Sementara itu, rancangan sistemnya dibuat menggunakan diagram konteks dan data flow diagram (DFD).Adapun tools yang digunakan adalah Delphi 7, phpMyAdmin 4.5.1 dan XAMPP 3.2.2. Hasil pengujian sistem menunjukkan bahwa selain mempermudah pengelolaan data, aplikasi pengolah data bantuan sosial mampu menyajikan hasil output berupa laporan yang mempermudah hasil rekapitulasi data yang dibutuhkan personal maupun data.Selain itu, disarankan juga untuk memperbaiki form data pembagian sembako, kelompok usaha bersama, dan bedah rumah lebih kompleks seperti hal nya saat penerimaan data selesai atau sudah terealisasi mendapatkan notifikasi sms kepada pemohon bantuan.
\end{abstract}

Kata Kunci : Aplikasi, Bantuan Sosial, Delphi 7, Xamp.

\section{PENDAhULUAN}

$\mathrm{P}$ ENYANDANG Masalah Kesejahteraan Sosial (PMKS) adalah masalah yang tidak ada habis-habisnya di Negara kita. PMKS merupakan Individu atau kelompok yang memiliki suatu kesulitan dikarenakan adanya gangguan dalam permasalahan sosial sehingga mengakibatkan kurang mampunya dalam melakukan fungsi sosial dan hubungan dengan lingkungannya serta kurang mampu dalam pemenuhan kebutuhan jasmani maupun rohani secara normal dan pada 19 Agustus 1945 dibentuk Kementerian Kesejahteraan Sosial RI, seiring perjalanan waktu menjadi Departemen Sosial RI.

Kategori PMKS sendiri berjumlah 26 macam dengan kriteria-kriteria tertentu berdasarkan Peraturan Menteri Sosial Republik Indonesia No. 8 Tahun 2012 dan salah satunya fakir miskin. Fakir miskin adalah orang yang sama sekali tidak mempunyai sumber mata pencaharian atau mempunyai sumber mata pencaharian tetapi tidak mempunyai kemampuan memenuhi kebutuhan dasar yang layak bagi kehidupan dirinya atau keluarganya. Dinas sosial prov. Kalsel khususnya di bidang penanganan fakir miskin mempunya 3 program bantuan yang pertama sembako, bedah rumah dan kelompok usaha bersama

Kebijakan ini di rasa sangat berat oleh sebagian masyarakat khususnya bagi mereka yang terkena dampak dari kebijakan ini dan mengingat dampak yang ditimbulkan dari berbagai aspek kehidupan. Untuk itu, setiap masing-masing pemerintah daerah yang ada di Kalimantan Selatan harus memiliki program dan pelaksanaan yang matang pada saat proses pembagian bantuan sosial dengan tujuan agar bantuan dapat tersalurkan dengan baik dan tepat sasaran sesuai dengan kriteria terhadap bantuan sosial tersebut

Adapun tujuan untuk terciptanya aplikasi ini adalah:

1. Terwujudnya sumber daya manusia (SDM) yang mampu untuk melaksanakan pembangunan kesejahteraan sosial

2. Terwujudnya kemauan dan kemampuan penyandang masalah kesejahteraan sosial (PMKS) guna memperbaiki taraf kesejahteraan sosial yang didasarkan atas kesetiakawanan sosial.

3. Terwujudnya kualitas dan efektifitas rehabilitasi bagi penyandang masalah kesejahteraan sosial (PMKS).

4. Terwujudnya kesadaran dan tanggung jawab masyarakat / potensi sumber kesejahteraan sosial dalam usaha kesejahteraan sosial serta kesiapsiagaan dalam usaha pencegahan dan penanggulangan akibat bencana.

5. Terwujudnya sarana dan prasarana kesejahteraan sosial yang memadai untuk mendukung pembangunan kesejahteraan sosial.

6. Meningkatkan kemampuan dan kemauan keluarga rentan, keluarga fakir miskin, keluarga berumah tidak layak huni, nilai keperintisan dan kepahlawanan, keluarga pahlawan nasional, komunitas adat terpencil dan meningkatkan kualitas penyuluhan sosial.

\section{METODE PENELITIAN}

Adapun metode penelitian yang digunakan untuk mengumpulkan data-data yang diperlukan adalah sebagai berikut:

1. Observasi

Observasi dilakukan di Dinas Sosial Provinsi Kalimantan Selatan untuk melihat secara langsung bagaimana prosedur alur dari kegiatan bantuan sosial untuk mendapatkan datadata yang berkaitan dengan kegiatan tersebut untuk selanjutnya diolah menjadi informasi yang baru. 
2. Wawancara

Wawancara dilakukan beberapa kali dengan narasumber yang berbeda yang terlibat dengan objek yang di teliti agar mendapatkan data validasi yang benar

\section{Metode Analisis Sistem Yang Berjalan}

Analisa sistem yang sedang berjalan sangat dibutuhkan dalam perancangan sistem informasi, dari hasil observasi dan wawancara maka penulis dapat menggambarkan proses pengolahan data dan penginputan data bantuan sosial. Adapun proses-proses yang dilakukan dalam pengolahan data dan penginputan sebagai berikut :

1) Proses daftar pemohon bantuan.

2) Proses input data wilayah pmks.

3) Proses input data orang terlantar.

4) Proses input anggaran.

5) Proses input kegiatan.

6) Proses input rekanan.

7) Proses input data pembagian sembako, kube, dan bedah rumah.

8) Hasil laporan rekapitulasi keseluruhan dan Berita Acara.

\section{Metode Analisis Kebutuhan Sistem}

Proses pengolahan data bantuan sosial bagi penyandang masalah kesejahteraan sosial pada dinas sosial provinsi kalimantan saat ini memang sudah terkomputerisasi. Akan tetapi proses tersebut masih kurang efektif dan efisien. Selain itu, belum adanya sistem keamanan yang memadai membuat data sangat rawan akan tindakan manipulasi dari pihak-pihak tertentu yang tidak bertanggung jawab. Berdasarkan permasalahan inilah maka diusulkan untuk membuat aplikasi bantuan sosial bagi penyandang masalah kesejahteraan sosial berbasis desktop. Adapun software sistem yang dibutuhkan adalah sistem operasi Windows 8, Delphi 7 dan XAMPP 3.2.2. Sementara hardware yang dibutuhkan adalah sebuah laptop dengan processor intel core $\mathrm{i5,} \mathrm{RAM} 2$ GB dan harddisk 1 TB.

\section{Rancangan Model Sistem}

Adapun rancangan model sistem aplikasi pengolah data siswa dan mahasiswa praktik ini adalah sebagai berikut:

\section{Diagram Konteks}

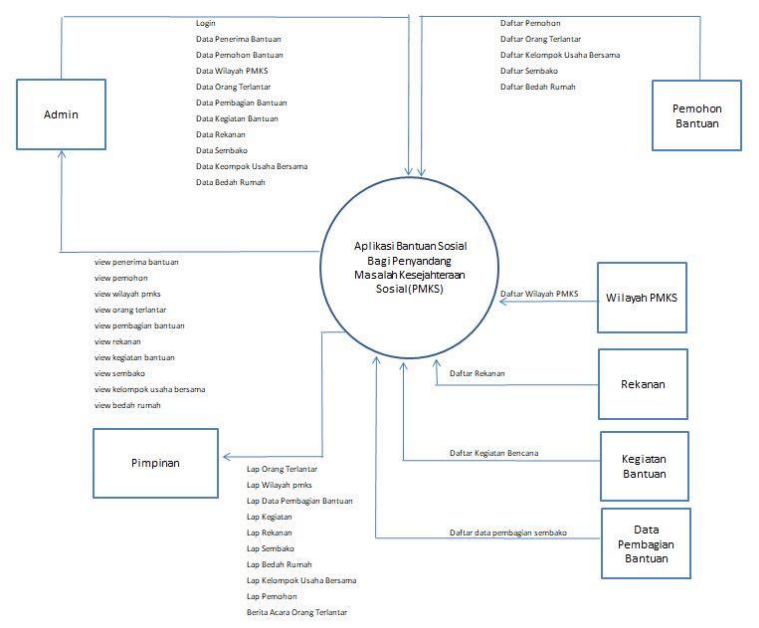

2. DFD Level 1

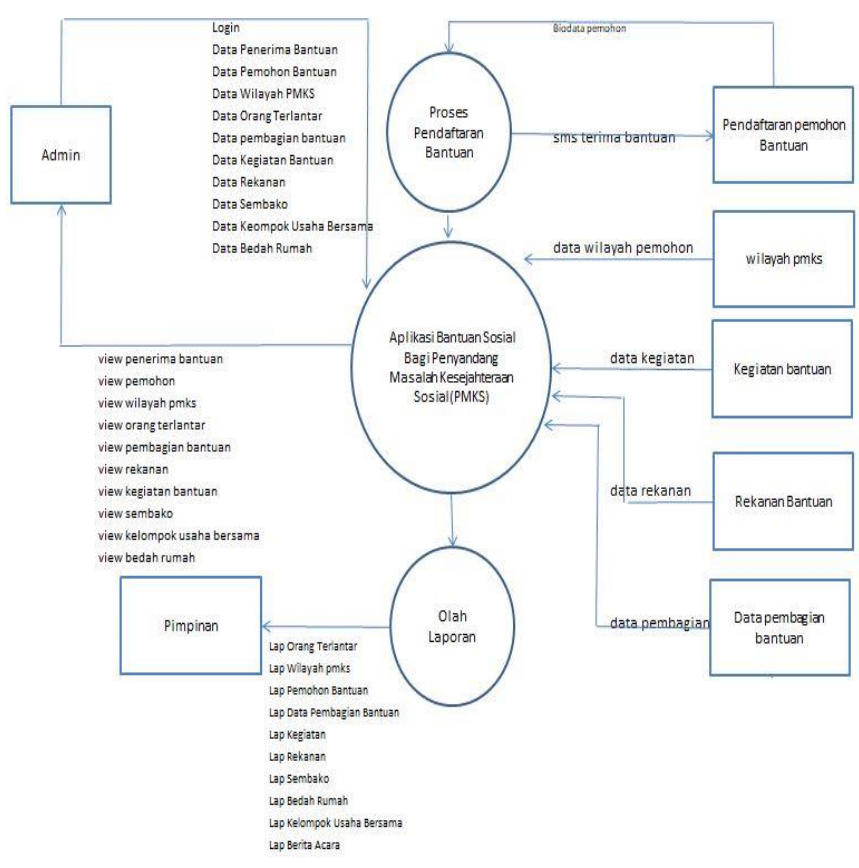

\section{HASIL DAN PEMBAHASAN}

\section{A. Spesifikasi Sistem}

Adapun spesifikasi hardware dan software yang diperlukan dalam penerapan aplikasi bantuan sosial bagi penyandang masalah kesejahteraan sosial pengolah sebagai berikut :

1. Spesifikasi hardware
a. Processor intel core i5
b. RAM 2 GB
c. Harddisk $1 \mathrm{~TB}$

2. Spesifikasi software
a. Windows 8
b. Delphi 7
c. PhpMyAdmin 4.5.1
d. XAMPP 3.2.2

\section{B. Langkah Langkah Pembuatan Sistem}

Proses pembuatan aplikasi bantuan sosial bagi penyandanga masalah kesejahteraan sosial ini menggunakan model waterfall. Model ini melakukan pendekatan secara sistematis dan urut, mulai dari analisis kebutuhan sistem, perancangan sistem, koding, pengujian dan maintenance. Adapun langkah-langkahnya adalah sebagai berikut:

1. Analisis persyaratan dan kebutuhan

Pada tahapan ini dilakukan pengumpulan data dan informasi yang berkaitan dengan penerima bantuan. Informasi ini diperoleh melalui dengan cara terjun langsung ke lapangan dan mewawancarai beberapa orang narasumber. Data dan informasi yang telah didapatkan selanjutnya akan dianalisis untuk mendapatkan dokumentasi kebutuhan pengguna dan digunakan pada tahapan selanjutnya. 
2. Desain sistem

Tahapan selanjutnya adalah membuat rancangan untuk aplikasi bantuan sosial bagi penyandang masalah kesejahteraan sosial. Rancangan yang dibuat ini meliputi rancangan model sistem, rancangan antarmuka masukan sistem hingga rancangan antarmuka keluaran sistem.

3. Implementasi

Tahapan selanjutnya adalah mulai membangun sistem. Aplikasi bantuan sosial bagi penyandangan masalah kesejahteraan sosial ini menggunakan aplikasi Delphi 7.

4. Testing

Pada tahapan ini aplikasi yang sudah selesai diprogram akan dilakukan proses pengujian. Pengujian ini dilakukan untuk memeriksa apakah fungsi aplikasi yang dibangun sudah sesuai dengan tujuan dan keinginan.

5. Maintenance

Setelah lolos tahap pengujian, tahapan selanjutnya adalah menerapkan aplikasi bantuan sosial bagi penyandang masalah kesejahteraan sosial ini pada instansi Dinas Sosial Provinsi Kalimantan Selatan.

\section{Tampilan Aplikasi \\ 1. Form Login}

Untuk halaman login ini digunakan admin untuk membatasi hak akses seseorang dimana pada halaman perancangan login ini ada dua input text username dan password (kata sandi) dan tombol proses masuk. Apabila ada seseorang yang ingin memasuki sistem informasi ini selain pengguna yang sudah memiliki hak akses sepenuhnya untuk sistem ini tidak akan diproses kehalaman selanjutnya yaitu halaman utama sistem selanjutnya.

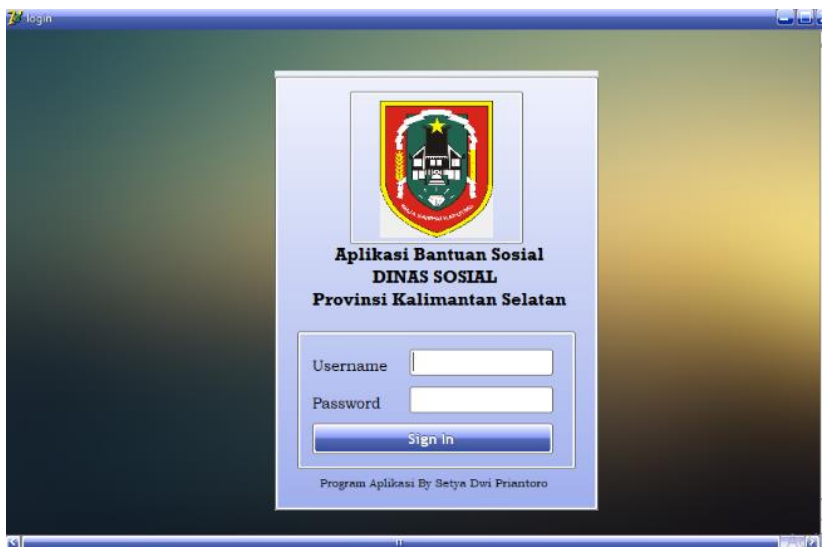

\section{Form Menu Utama}

Gambar di bawah ini merupakan tampilan menu utama admin. Admin memiliki hak akses untuk dapat memanipulasi semua data yang ada dalam sistem. Form ini terdiri dari 6 buah menu, yaitu menu penerima bantuan, data penyandang masalah kesejahteraan sosial (pmks) yang berisi sub menu yaitu wilayah pmks, orang terlantar, pemohon bantuan, dan bantuan berisi sub menu yaitu penerima sembako, bedah rumah, kelompok usaha bersama, dan daftar terdiri dari 3 sub menu yaitu daftar anggaran, daftar kegiatan dan daftar rekanan. Menu laporan memiliki laporan orang terlantar, laporan wilayah pmks, laporan penerima bantuan, laporan anggaran dana, laporan kegiatan, laporan rekanan, laporan sembako, laporan bedah rumah, laporan kelompok usaha bersama.

\section{Form Menu Utama}

Gambar di bawah ini merupakan tampilan menu utama admin. Admin memiliki hak akses untuk dapat memanipulasi semua data yang ada dalam sistem. Form ini terdiri dari 6 buah menu, yaitu menu penerima bantuan, data penyandang masalah kesejahteraan sosial (pmks) yang berisi sub menu yaitu wilayah pmks, orang terlantar, pemohon bantuan, dan bantuan berisi sub menu yaitu penerima sembako, bedah rumah, kelompok usaha bersama, dan daftar terdiri dari 3 sub menu yaitu daftar anggaran, daftar kegiatan dan daftar rekanan. Menu laporan memiliki laporan orang terlantar, laporan wilayah pmks, laporan penerima bantuan, laporan anggaran dana, laporan kegiatan, laporan rekanan, laporan sembako, laporan bedah rumah, laporan kelompok usaha bersama.

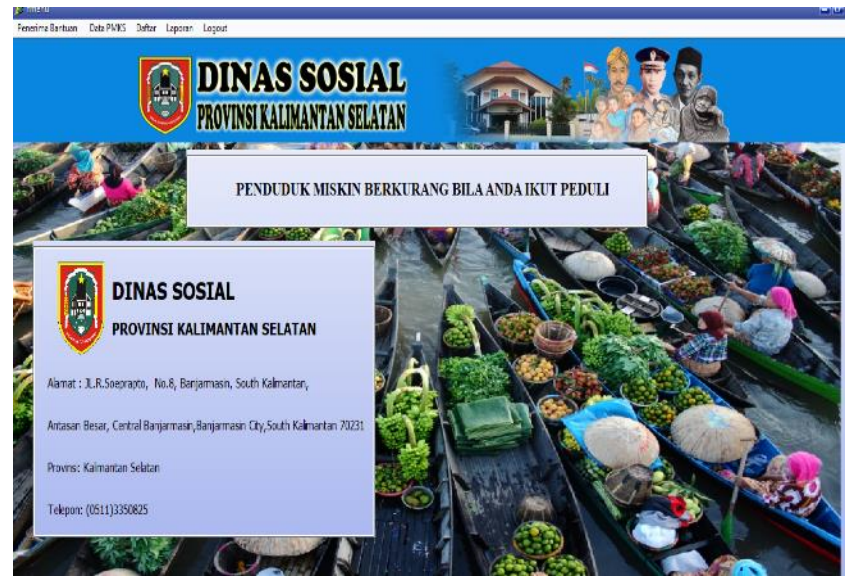

\section{Form Penerima Bantuan}

Gambar di bawah ini merupakan tampilan penerima bantuan. Form ini untuk meng-input atau mendaftar penerima bantuan secara lengkap untuk mengetahui dari setiap penerima bantuan keseluruhan yang akan dipisahkan dalam beberapa tahapan yang akan di teruskan ke pemohon bantuan sesuai dengan kategori penerima bantuan contoh apakah penerima bantuan ini di kategorikan orang terlantar, penerima sembako, penerima bedah rumah maupun kelompok usaha bersama sesuai dengan biodata penerima bantuan yang berlangsung.

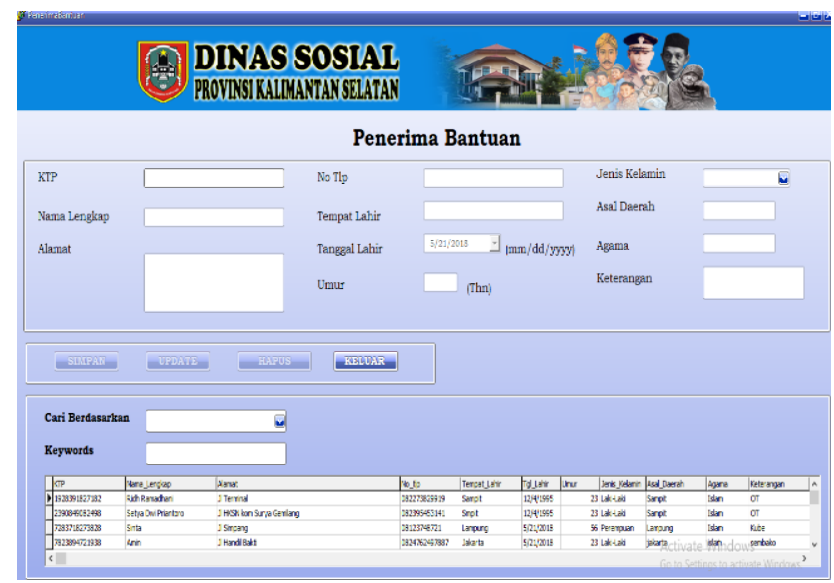




\section{Form Wilayah Penyandang Masalah Kesejahraan Sosial (PMKS)}

Pada halaman data wilayah PMKS ini untuk meng-input dan mendata penyandang masalah kesejahteraan sosial sebagai contoh mendata banyaknya fakir miskin, banyaknya rumah tak layak huni, banyaknya pengangguran yang terdapat di wilayah tersebut agar menjadi capaian kerja target Dinas Sosial sesuai dengan peraturan yang berlaku dan pada halaman data wilayah PMKS ini yaitu ada tombol tambah data, update data dan tombol untuk menghapus data wilayah PMKS yang sudah diinput-kan atau sudah disimpan sebelumnya.

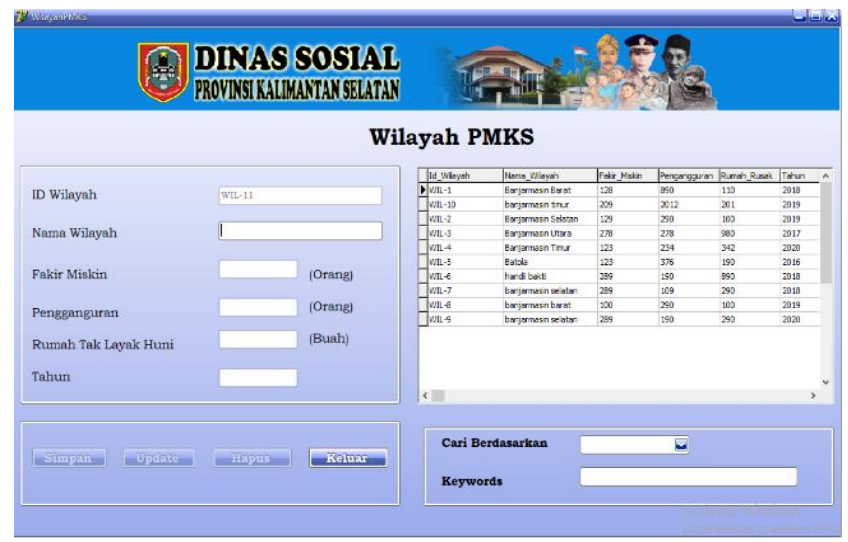

\section{Form Pemohon Bantuan}

Pada halaman data pemohon bantuan ini hanya untuk perorangan karena data pemohon ini bersifat data pribadi maka peng-input-an data tersebut sesuai dengan biodata pemohon dan juga pemohon juga boleh menentukan apakah pemohon tersebut memilih untuk menerima sembako,bedah rumah atau kelompok usaha bersama dan juga harus sesuai dengan kriteria pemohon dan sesuai dengan sop yang berlaku agar dapat merealisasikan pemohon dan pada halaman data pemohon bantuan ini ada tombol tambah data, update data dan tombol untuk menghapus data pemohon yang sudah di-inputkan atau sudah disimpan sebelumnya.

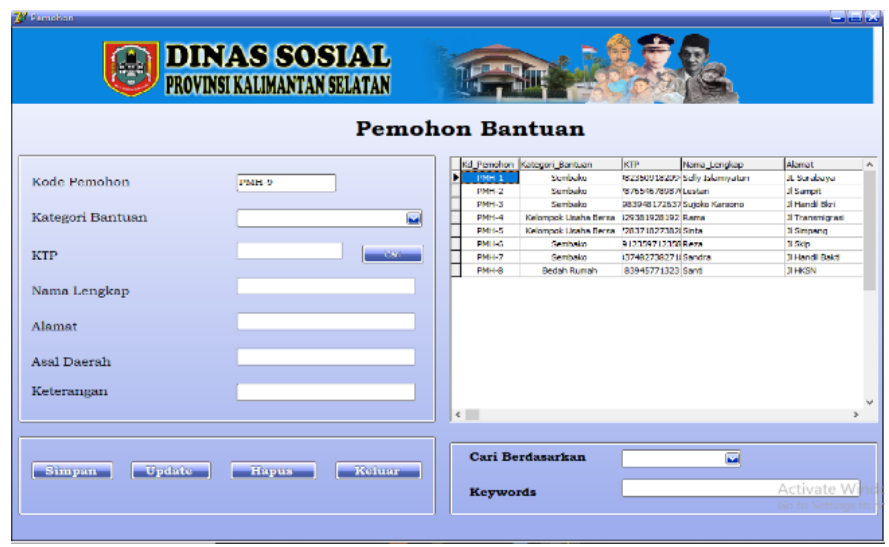

\section{Form Data Pembagian Bantuan}

Gambar di bawah ini merupakan tampilan form untuk menginputkan data pembagian bantuan sesuai dengan tahun anggaran penerimaan bantuan berupa anggaran sembako, anggaran bedah rumah, dan anggaran kelompok usaha bersama.

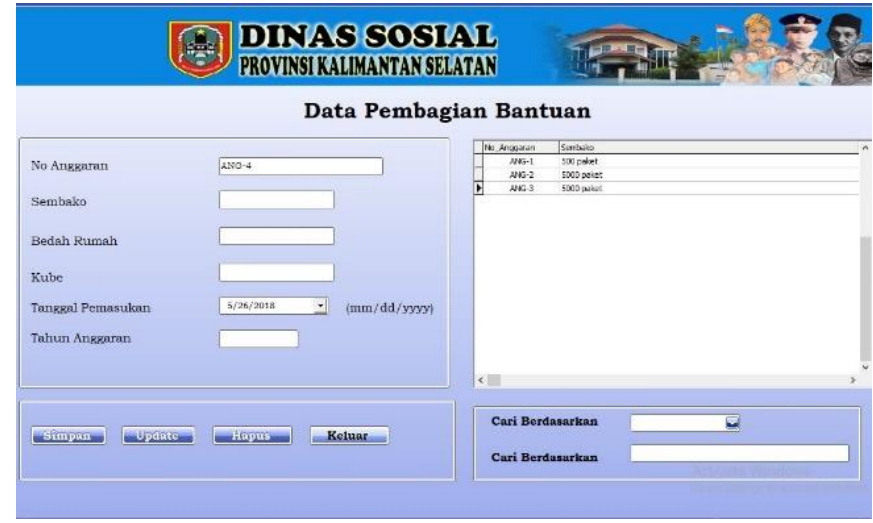

\section{Form Rencana Kegiatan Bantuan}

Gambar di bawah ini merupakan tampilan form untuk memasukkan data kegiatan rencana bantuan yang akan di realisasikan di tahun berikutnya agar setiap bantuan dapat terealisasikan dengan benar maka harus sesuai dengan kegiatan yang berlaku pada kegiatan rencana bantuan.

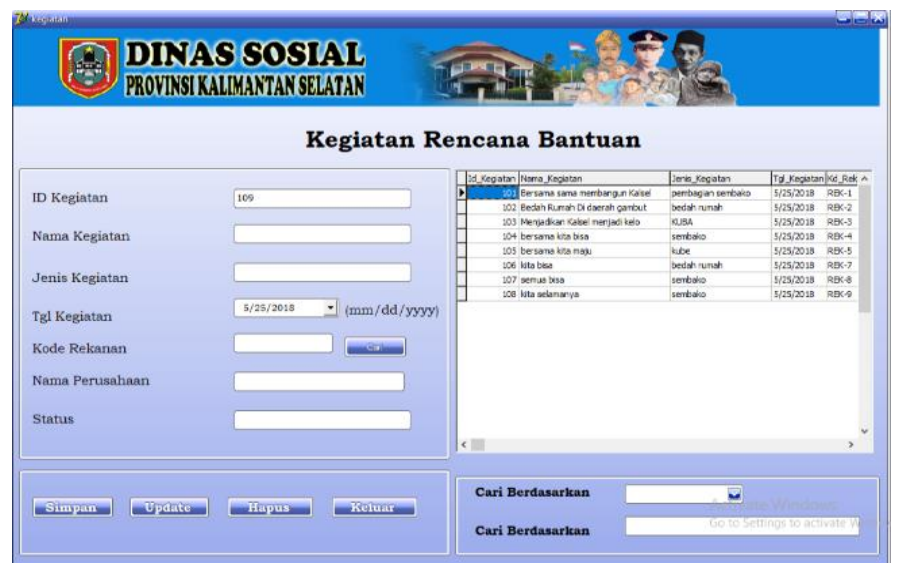

\section{Form Sembako}

Pada halaman data penerima sembako ini terdapat di sub menu daftar penerima dan fungsi nya adalah untuk menginput dan verifikasi data apakah penerima sembako ini sudah atau belum dalam menerima sembako tersebut dan pada halaman data penerima sembako ini yaitu ada tombol tambah data, update data dan tombol untuk menghapus data penerima sembako yang sudah di-input-kan atau sudah disimpan sebelumnya.

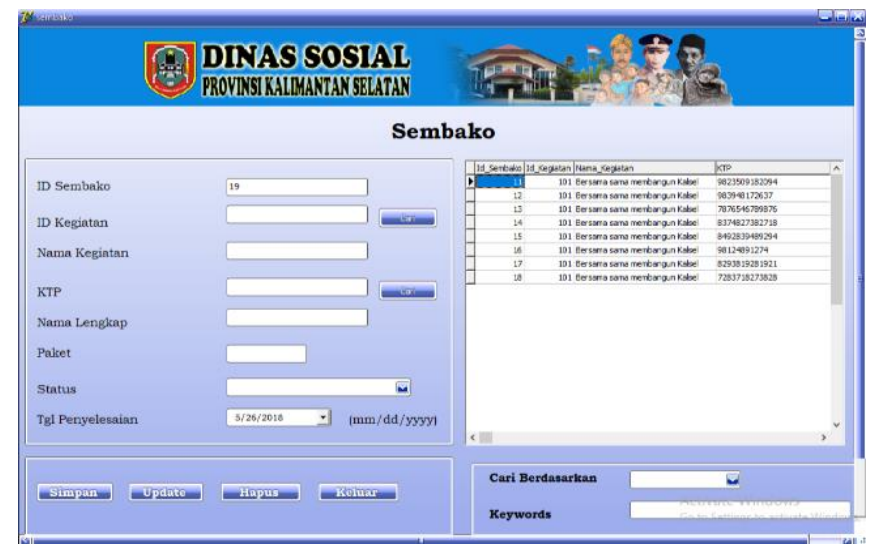




\section{Form Bedah Rumah}

Pada halaman data bedah rumah ini sama halnya dengan penerima sembako yaitu terdapat di sub menu daftar penerima dan fungsi nya adalah untuk menginput dan verifikasi data apakah penerima bedah rumah ini sudah atau belum dalam menerima bedah rumah tersebut dan pada bedah rumah terdapat nominal yang di targetkan sesuai dengan anggaran yang berlaku dan pada halaman data penerima bedah rumah ini yaitu ada tombol tambah data, update data dan tombol untuk menghapus data yang sudah diinputkan atau sudah disimpan sebelumnya.

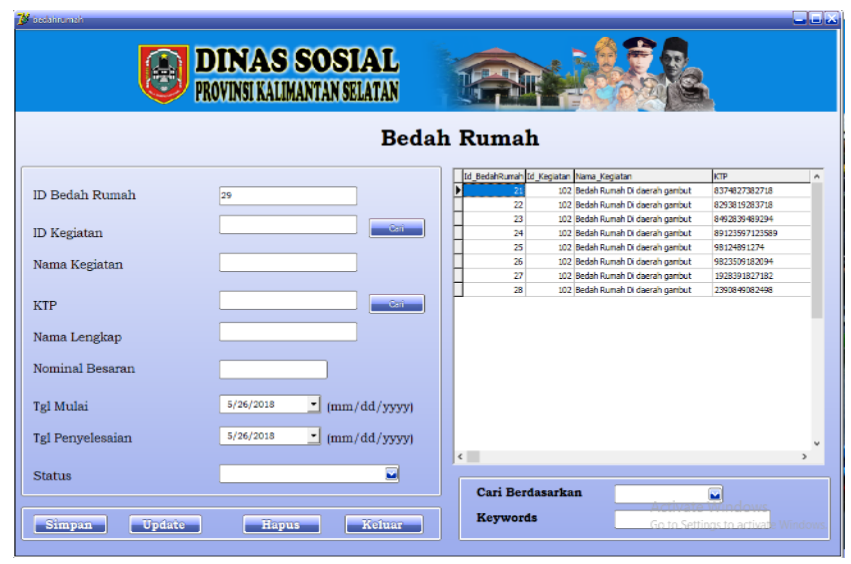

\section{Form Cetak Laporan Pemohon Bantuan}

Gambar di bawah ini merupakan tampilan form untuk mencetak laporan pemohon bantuan dan untuk mempermudah pencarian dan cetak laporan maka pencarian dapat berdasarkan kode pemohon, KTP dan kategori bantuan.

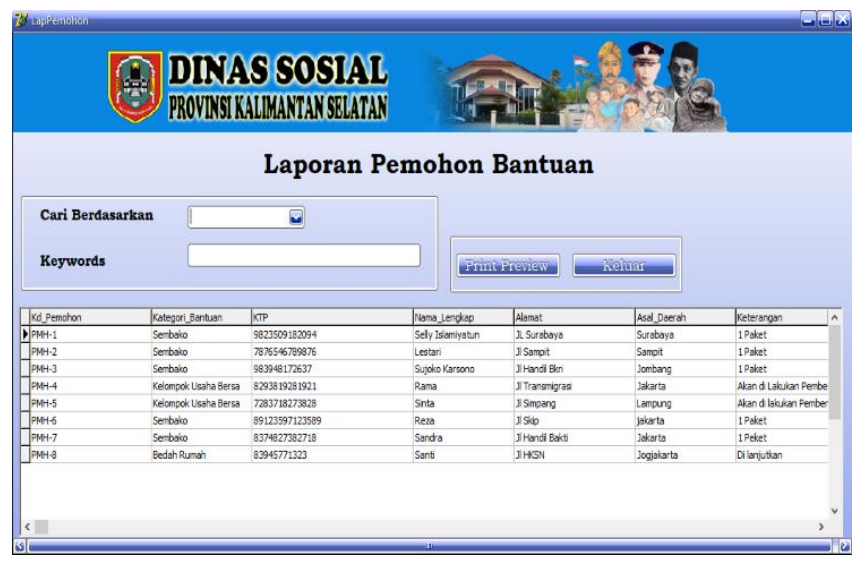

\section{KESIMPULAN}

Adapun kesimpulan dalam penelitian ini adalah sebagai berikut:

1. Aplikasi bantuan sosial bagi penyandang masalah kesejahteraan sosial ini dapat membantu para admin yang mengelola data bantuan sosial lebih mudah dan efektif.

2. Aplikasi bantuan sosial bagi penyandang masalah kesejahteraan sosial ini dapat menyajikan laporan secara cepat dan akurat.

3. Sistem dapat menghitung dana rekanan secara otomatis.
4. Mengurangi penyalahgunaan hak akses oleh pihak-pihak tak bertanggung jawab.

5. Pemohon Bantuan dapat cepat terealisasikan permohonannya agar dapat terlaksana dengan benar.

6. Dapat mengurangi resiko duplikasi dan kerusakan data selama proses penginputan

7. Admin dapat melakukan penginputan penerima bantuan dan membagi semua kebutuhan bantuan agar sesuai dengan capain target.

\section{V.SARAN}

Penelitian ini masih sangat jauh dari kata sempurna dan memiliki banyak kekurangan. Adapun saran untuk penelitian selanjutnya adalah sebagai berikut:

1. Saat penyaluran bantuan dikonfirmasi agar dapat mengirim sms ke pemohon bantuan seperti saat daftar penerima bantuan tersebut.

2. Laporan berita acara dari setiap bantuan agar dapat di laporkan.

3. Adanya cara untuk registrasi melalui sms pemohon agar mempermudah akses jarak saat adanya bantuan sosial di lakukan.

4. Akan lebih baik lagi jika aplikasi ini dikembangkan menjadi aplikasi berbasis web agar informasi seputar bantuan sosial di Dinas Sosial Provinsi Kalimantan Selatan agar dapat di lihat di UPTD/UPT lain nya

\section{DAFTAR PUSTAKA}

[1] Dinsos Kalsel. (2017). Sejarah Dinas Sosial Provinsi Kalimantan Selatan. Diperoleh 9 Juli 2018, dari http://dinsos.kalselprov.go.id/profil/sejarah.

[2] Ibrahim. (2004). Manajemen Perlengkapan Sekolah Teori dan Aplikasinya. Jakarta: Bumi Aksara.

[3] Ichwan, Muhammad. 2011. Pemrograman Basis Data : Microsoft Visual Basic 6.0 dan MySql. Bandung : Informatika

[4] Jogiyanto, H. (2008). Pedoman Survei Kuesioner, Mengembangkan Kuesioner, Mengatasi Bias dan Meningkatkan Respon. Yogyakarta: BPFE Yogyakarta.

[5] Kemensos. (2017). Bantuan Sosial. Diperoleh 9 Juli 2018, dari https://www.kemsos.go.id/content/bantuan-sosial.

[6] Khaidir. (2004). Microsoft Visual Basic 6.0. Jakarta: Elex Media Komputindo.

[7] Kusnassriyanto. (2011). Belajar Pemrograman Delphi. Bandung : Modula

[8] Raharjo, Budi. (2011). Belajar Otodidak Membuat Database Menggunakan MySql. Bandung : Informatika

[9] Riyanto. (2014). Membuat Sendiri Aplikasi Web Store dengan PHP, JQuery dan Microsoft SQL Server. Yogyakarta: Gava Media.

[10] Supriyanto. (2005). Perancangan Aplikasi. Surabaya: Widyastana. 